\title{
Metacognitive awareness of commuter and resident students of Islamic high school in biology learning
}

\author{
Afifah Putri Sari a,1, Puguh Karyanto a,2,* A. Ashadi a,3 \\ a Magister of Science Education, Faculty of Teacher Training and Education, Universitas Negeri Sebelas Maret, Jl. Ir. Sutami 36 A, \\ Surakarta, Central Java, 57727, Indonesia \\ afifahputrisari30@gmail.com; ${ }^{2}$ puguhkaryanto@staff.uns.ac.id * ; ${ }^{3}$ ashadiuns2014@gmail.com \\ * Corresponding author
}

\begin{tabular}{|c|c|}
\hline ARTICLE INFO & ABSTRACT \\
\hline $\begin{array}{l}\text { Article history } \\
\text { Received April 18, 2019 } \\
\text { Revised November 20, } 2019 \\
\text { Accepted February 24, } 2020 \\
\text { Published March 31, } 2020 \\
\text { Keywords } \\
\text { Commuter students } \\
\text { Islamic high school } \\
\text { Metacognitive awareness } \\
\text { Resident students }\end{array}$ & 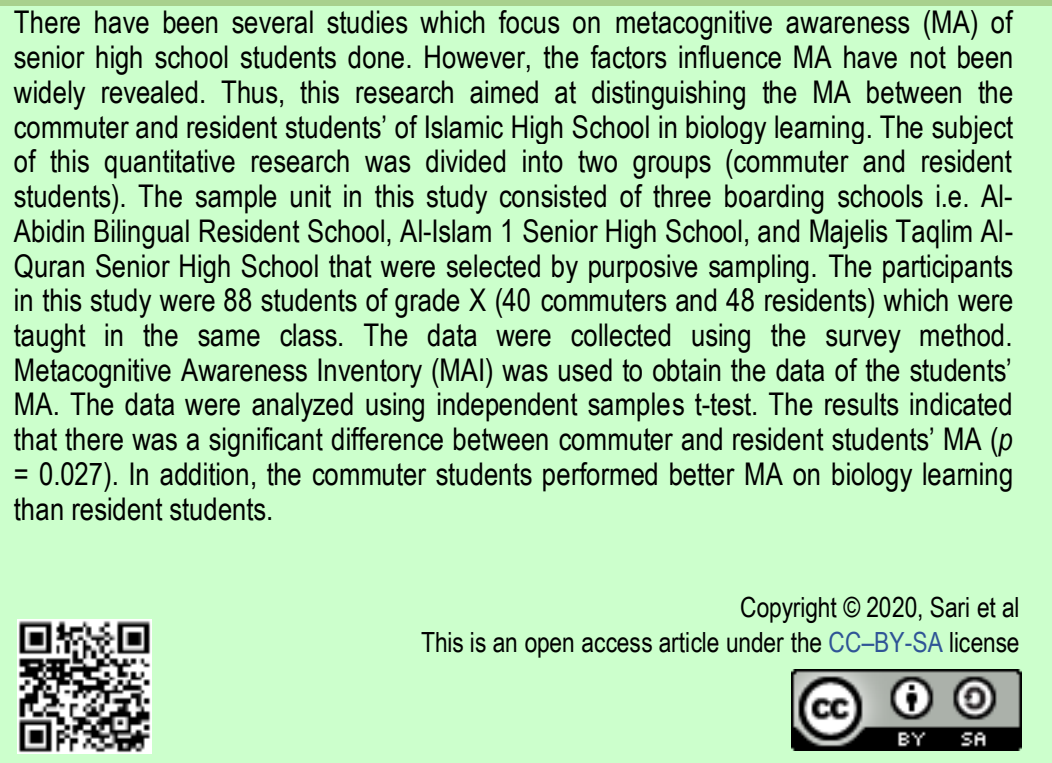 \\
\hline $\begin{array}{r}\text { How to cite: Sari, A. P., Ka } \\
\text { High School ir } \\
\text { jpbi.v6i1.8257 }\end{array}$ & $\begin{array}{l}\text { Ashadi, A. (2020). Metacognitive awareness of commuter and resident students of Islamic } \\
\text { ning. JPBI (Jurnal Pendidikan Biologi Indonesia), 6(1), 25-30. doi: https://doi.org/10.22219/ }\end{array}$ \\
\hline
\end{tabular}

\section{INTRODUCTION}

The development of $21^{\text {st }}$-century learning emphasizes the importance of the correlation between learning innovation and the attainment of the skills that modern students must possess (Glaze, 2018; Reeve, 2016; Scott, 2015). The research focus of the educational experts always leads to the achievement of these essential skills (Miharja, Hindun, \& Fauzi, 2019; Siswati \& Corebima, 2017a; Veenman, Hesselink, Sleeuwaegen, Liem, \& Van Haaren, 2014). Metacognition, one of the essential skills of the 21 stcentury, has been widely studied in various countries, both in developed and developing countries (Akyol, Sungur, \& Tekkaya, 2010; McComas et al., 2018). Moreover, metacognitive research is also carried out at various levels of education, i.e. primary (Tzohar-Rozen \& Kramarski, 2014), secondary (Naimnule \& Corebima, 2018), and higher education (Panchu, Bahuleyan, Seethalakshmi, \& Thomas, 2016). Researchers believe that metacognition is the essential factors responsible for learning success (Adnan \& Bahri, 2018; Ayazgök \& Aslan, 2014; Dwyer, Hogan, \& Stewart, 2014). Thus, the identification and development of metacognitive skills need to be continuously developed. 
The development of metacognitive skills is based on various factors (Arslan, 2015; Goh \& Hu, 2014; Jagals \& Walt, 2016). These factors are indicated to be closely related to the development of students' metacognition skills such as self-awareness (Kallio, Virta, \& Kallio, 2018; Okoza, Aluede, \& Owens-Sogolo, 2013), learning that activates thinking skills (Bensley \& Spero, 2014; Dwyer et al., 2014; Miharja et al., 2019), to a conducive learning environment (Tzohar-Rozen \& Kramarski, 2014). Metacognition that is constantly sharpened through activities carried out routinely has a significant impact on improving metacognitive skills (Jagals \& Walt, 2016). The routine gradually strengthens the students' self-regulation so that they are able to control the activities they do (Kruit, Oostdam, Berg, \& Schuitema, 2018; Panchu et al., 2016).

The environment, according to some experts, plays a significant role in the development of students' metacognition skills (Aurah, 2013; Gul \& Shehzad, 2012; Lee et al., 2011). Students who grow up in a conducive environment have a psychological environment that is adaptive to the development of metacognition (Kisa \& Stein, 2015; Muwonge, Schiefele, \& Ssenyonga, 2017). Interestingly, the student learning environment is not limited to where students get knowledge but also to where students live. According to the concept of lifelong learning, wherever students are in a learning environment due to interactions between them. Interestingly, in Indonesia, the student's living environment is not only at home but also in a dormitory for students studying at an Islamic boarding school.

Research on developing skills and metacognitive awareness (MA) focuses a lot on the work that can be done in classroom learning (Aurah, 2013; Bensley \& Spero, 2014; Goh \& Hu, 2014; Okoza et al., 2013). Earlier studies showed that modern Islamic school has gained the interest of many researchers around the world to uncover history and the student's activity and outcomes, such as modern Islamic school in Singapore \& Britain (Tan, 2011), Victoria (Hassen, 2013), Bangladesh (Asadullah, 2016), and North America (Memon, 2011). However, it does not explicitly distinguish how MA develops based on different learning environments. This research aimed at distinguishing the MA between the commuter and resident students' of Islamic High School in biology learning.

\section{METHOD}

This research was quantitative research. The focus of this research is the students' MA. The research was conducted at a moder Islamic school in Surakarta. The commuter and resident students in each school taught in the same classroom. The unit samples were Al Abidin Bilingual Boarding School, Senior High School of Al Islam 1, and Senior High School of Majelis Taqlim Al Quran. Purposive random sampling was used to select the participants. The sample units are schools that have dormitories, and students learn in heterogeneous classes. Samples of this research were X-6 of Al-Abidin Bilingual Boarding School, X-4 of Senior High School of Al-Islam 1, and X-5 of Senior High School of Majelis Taqlim Al Quran.

The data were collected using the Metacognitive Awareness Inventory (MAl) questionnaire developed by Schraw and Dennison (1994). The MAl instrument, consist of 52 questions, was tested to 88 students of grade $\mathrm{X}$ (40 commuter students; 48 resident students). The questionnaire is divided into four classification, i.e 1 (strongly disagree), 2 (disagree), 3 (agree), and 4 (strongly agree). The MAl is divided into two aspects namely knowledge and regulation of cognition. Knowledge of cognition aspect has three indicators such as declarative knowledge, procedural knowledge, and conditional knowledge. Regulation of cognition aspect has six indicators such as planning, information management strategies, monitoring, debugging strategies, and evaluation.

The Cronbach's alpha at the 0.05 level was used for the MAl instrument. The coefficient of Cronbach's alpha is the measurement for reliability test. The normality data was checked by using Kolmogorov-Smirnov for adequate assumption in conducting independent sample t-test to analyze the students' MA.

\section{RESULTS AND DISCUSSION}

The results of Cronbach-alpha analysis were shown in Table 2 . The obtained alpha (a) value was 0.935 . It showed that the instrument was reliable and can be used in research.

Table 2. The results of reliability test of the MAI

\begin{tabular}{cc}
\hline Cronbach's Alpha & N of Items \\
\hline .935 & 52 \\
\hline
\end{tabular}

The significant scores for the commuter students were 0.697 , and for the resident students was 0.463 . It showed the data were normally distributed. After the normality test was examined, the descriptive statistic of the data was shown in Table 3. It shows that most of the students, both commuter and resident, conducted 
high MA on biology learning. Moreover, the results of the independent sample t-test (Table 4) show that there were any differences in MA in both students (sig. value <0.05).

Table 3. Descriptive statistic of commuter and resident students

\begin{tabular}{cccccc}
\multicolumn{7}{c}{ Table 3. Descriptive statistic of commuter and resident students } \\
\hline Students & M & SE & Low (\%) & Moderate (\%) & High (\%) \\
\hline Commuter & 75 & 1.527 & 37.5 & 12.5 & 50.0 \\
Resident & 71 & 0.932 & 43.8 & 10.4 & 45.8 \\
\hline \multicolumn{7}{c}{ Table 4. The results of independent sample t-test } \\
\hline \multicolumn{7}{c}{ Statistic } & F & Sig. \\
\hline Values & Equal variance assumed & 5.064 & 0.027 \\
\hline
\end{tabular}

The results in Figure 1 show that commuter students show higher MA. These results indicate the influence of different living environments on the growth of MA. On the other hand, MA of resident students was less than commuter students. This result is contrary to research (Martin et al, 2014; Ogechukwu \& Chika, 2018) which says that the MA of resident students is higher.

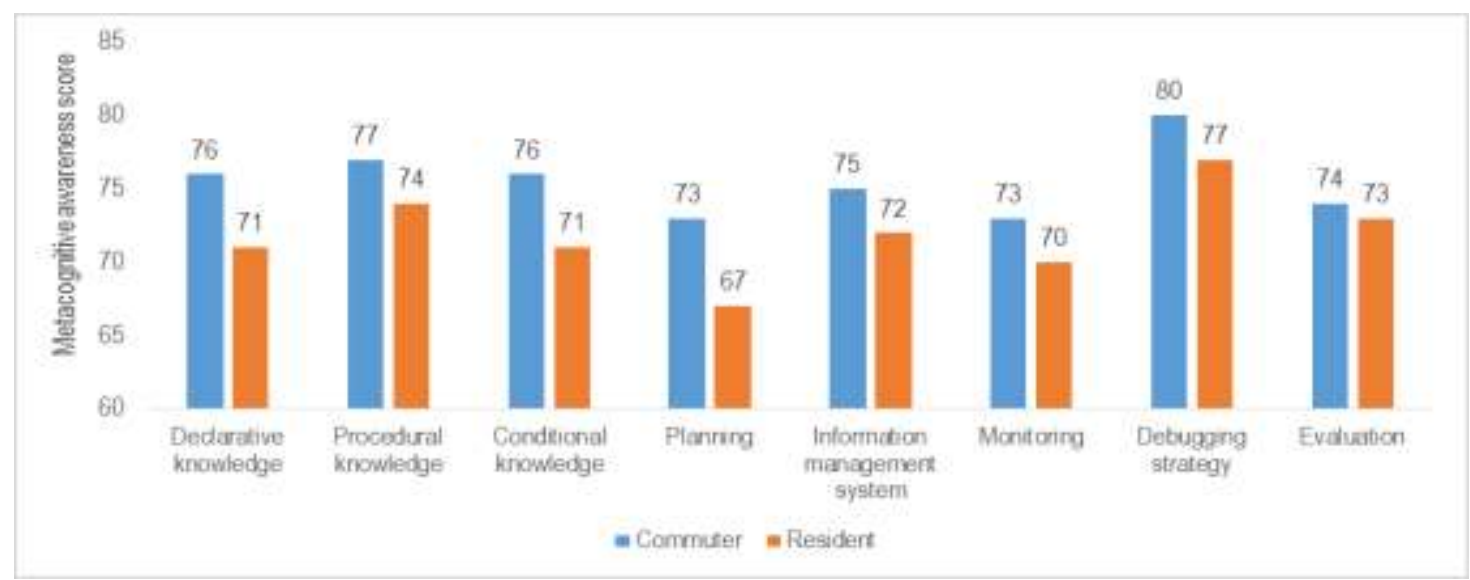

Figure 1. Metacognitive awareness of the commuter and resident students

MA of resident students was less than commuter students in this research that can be explained by the different experiences of them. Students who entered the boarding for the first time face the challenge of adapting to the new environment. Resident students must overcome the challenges of independent living and adapt to new rules in the boarding. The observation in the first year of resident students achieved fewer outcomes than the commuter students (Behaghel, Chaisemartin, \& Gurgand, 2017). The resident students have to overcome many challenges to adapt to the strict rules and situations which are exclusive for boarding programs. Students who are mature or experienced are predicted to be able to adapt quickly. This indicates that MA is closely related to biological age and experience (Fisher, 1998).

The results of this study contradict some researchers who claim boarding students achieve better than commuter students because boarding students are under the control of their studies (Martin et al., 2014; Ogechukwu \& Chika, 2018). Resident students who can adapt and accept new environments can find effective ways of learning Living together leads the positive effect to boarding students so they can learn how to manage their studies in the under control environment of boarding. Besides, factors that affect the MA include not only learning environment as external factors (Gul \& Shehzad, 2012) but also age, gender, personality, and intelligence as the internal factors (Martin et al., 2014; Siswati \& Corebima, 2017b). However, the experience of commuter and boarding students varies depending on what is in each individual as a learner (Laiser \& Makewa, 2016).

Besides, metacognition plays an essential role in managing the cognitive process. It means that high MA students might have a high cognitive learning outcome (Aurah, 2013). The commuter students performed a better MA than boarding students in this research might perform a better learning outcome. It can be because of their parent's support. Parent participation may be a factor that should be given attention because it affects the student's outcome (Mahuro \& Hungi, 2016). The excellent family parenting conducts good motivation for children, so it affects the learning achievement (Ambarwati, 2018; Aulia \& Khafid, 2018; Kaukab, 2016; Thoha \& Wulandari, 2016). In addition, age maturity is also an important factor that has an impact on MA (Song \& Bonk, 2016). The sample of this study is in the age range of $16-17$ years, which is psychologically in a period 
that requires assistance from parents or competent figures (Catalano, Hawkins, \& Toumbourou, 2008). Resident students, during this period, usually require a considerable amount of time and tend to vary among individuals (Logan, Lundberg, Roth, \& Walsh, 2017).

According to this result, MA's result that related the learning environment such as boarding school needs further investigation to limit other factors so the better result can be achieved. Overall, this research was conducted to reveal the MA that is needed in learning biology. Teachers, parents, and students themselves must actively participate to form an adaptive learning environment in fostering MA (Ambarwati, 2018; Pang, Lau, Seah, Cheong, \& Low, 2018). Another way to get a clearer result about the difference between MA of commuter and boarding students is by conducting the observation. Observation of students verbalized in biology learning is one of the ways to conceptualize MA. This point of view leads to the common features of what really happens in students when they face such a different situation and how MA becomes an important process in daily life students (Al-Hilawani, 2018).

MA can be elaborated as a students' tool to be better understanding biology. Students with good MA perform consciously to manage their knowledge. Then, find the difficulties in learning, and it can be overcome through an effective strategy. The experience plays an important role in leading the MA of students to become ready to plan, monitor, and evaluate for high achievement in biology learning (Ben-David \& Orion, 2013; Fisher, 1998; Muwonge et al., 2017).

\section{CONCLUSION}

The finding of the study shows that the commuter students performed better MA than resident students on biology learning in Islamic modern school Surakarta. This finding contributes to the topic of MA. However, further investigations are needed to ascertain the importance of MA in the role and learning.

\section{REFERENCES}

Adnan, A., \& Bahri, A. (2018). Beyond effective teaching: Enhancing students' metacognitive skill through guided inquiry. In Journal of Physics: Conference Series (Vol. 954, p. 12022). doi: https://doi.org/10.108 8/1742-6596/954/1/012022

Akyol, G., Sungur, S., \& Tekkaya, C. (2010). The contribution of cognitive and metacognitive strategy use to students' science achievement. Educational Research and Evaluation, 16(1), 1-21. doi: https://doi.org/ 10.1080/13803611003672348

Al-Hilawani, Y. A. (2018). Reflection on metacognition in real life situations: The truth is out there. Reflective Practice, 19(1), 135-144. doi: https://doi.org/10.1080/14623943.2017.1379982

Ambarwati, W. (2018). Influence of parents attention, emotional intelligence, and learning motivation to learning outcomes. Journal of Education, Teaching and Learning, 3(1), 72-81. doi: https://doi.org/10. 26737/jetl.v3i1.467

Arslan, S. (2015). Investigating predictive role of critical thinking on metacognition with structural equation modeling. The Malaysian Online Journal of Educational Science, 3(2), 1-10. Retrieved from http://ijie. um.edu.my/index.php/MOJES/article/view/12690

Asadullah, M. N. (2016). Trust, trustworthiness, and traditional Islamic education. Oxford Development Studies, 44(2), 152-166. doi: https://doi.org/10.1080/13600818.2015.1104294

Aulia, D. W., \& Khafid, M. (2018). Role of learning discipline in mediating the influence of parent's parenting towards student's learning achievement. Journal of Primary Education, 7(2), 155-162. doi: https://doi. org/10.15294/jpe.v7i2.23131

Aurah, C. (2013). The effects of self-efficacy beliefs and metacognition on academic performance: A mixed method study. American Journal of Educational Research, 1(8), 334-343. doi: https://doi.org/10.12691/ education-1-8-11

Ayazgök, B., \& Aslan, H. (2014). The review of academic perception, level of metacognitive awareness, and reflective thinking skills of science and mathematic university students. Procedia - Social and Behavioral Sciences, 141, 781-790. doi: https://doi.org/10.1016/j.sbspro.2014.05.137

Behaghel, L., Chaisemartin, C. de, \& Gurgand, M. (2017). Ready for boarding? The effects of a boarding school for disadvantaged students. American Economic Journal: Applied Economics, 9(1), 140-164. doi: https://doi.org/10.1257/app.20150090 
Ben-David, A., \& Orion, N. (2013). Teachers' voices on integrating metacognition into science education. International Journal of Science Education, 35(18), 3161-3193. doi: https://doi.org/10.1080/09500693.2 012.697208

Bensley, D. A., \& Spero, R. A. (2014). Improving critical thinking skills and metacognitive monitoring through direct infusion. Thinking Skills and Creativity, 12, 55-68. doi: https://doi.org/10.1016/j.tsc.2014.02.001

Catalano, R. F., Hawkins, D. J., \& Toumbourou, J. W. (2008). Positive youth development in the united states: History, efficacy, and links to moral and character education. In Handbook of moral and character education (pp. 459-483). New York: Routledge. Retrieved from http://dro.deakin.edu.au/view/DU

Dwyer, C. P., Hogan, M. J., \& Stewart, I. (2014). An integrated critical thinking framework for the 21st century. Thinking Skills and Creativity, 12, 43-52. doi: https://doi.org/10.1016/j.tsc.2013.12.004

Fisher, R. (1998). Thinking about thinking: Developing metacognition in children. Early Child Development and Care, 141(1), 1-15. doi: https://doi.org/10.1080/0300443981410101

Glaze, A. (2018). Teaching and learning science in the 21st century: Challenging critical assumptions in postsecondary science. Education Sciences, 8(1), 12. doi: https://doi.org/10.3390/educsci8010012

Goh, C. C. M., \& Hu, G. (2014). Exploring the relationship between metacognitive awareness and listening performance with questionnaire data. Language Awareness, 23(3), 255-274. doi: https://doi.org/10.108 0/09658416.2013.769558

Gul, F., \& Shehzad, S. (2012). Relationship between metacognition, goal orientation and academic achievement. Procedia - Social and Behavioral Sciences, 47, 1864-1868. doi: https://doi.org/10.1016/j. sbspro.2012.06.914

Hassen, Y. (2013). Making muslims: The politics of religious identity construction and Victoria's Islamic Schools. Islam and Christian-Muslim Relations, 24(4), 501-517. doi: https://doi.org/10.1080/09596410.2 013.813120

Jagals, D., \& Walt, M. Van Der. (2016). Enabling metacognitive skills for mathematics problem solving: a collective case study of metacognitive reflection and awareness. African Journal of Research in Mathematics, Science and Technology Education, 20(2), 154-164. doi: https://doi.org/10.1080/18117 295.2016.1192239

Kallio, H., Virta, K., \& Kallio, M. (2018). Modelling the components of metacognitive awareness. International Journal of Educational Psychology, 7(2), 94-122. doi: https://doi.org/10.17583/ijep.2018.2789

Kaukab, S. R. (2016). The impact of parent/family involment on student' learning outcome. International Journal of Research Granthaalayah, 4(10), 72-81. doi: https://doi.org/10.5281/zenodo.164925

Kisa, M. T., \& Stein, M. K. (2015). Learning to see teaching in new ways: American Educational Research Journal, 52(1), 105-136. doi: https://doi.org/10.3102/0002831214549452

Kruit, P.M., Oostdam, R.J., Berg, E.V.D., \& Schuitema, J. A. (2018). Assessing students' ability in performing scientific inquiry: Instruments for measuring science skills in primary education. Research in Science \& Technological Education, 36(4), 413-439. doi: https://doi.org/10.1080/02635143.2017.1421530

Laiser, S., \& Makewa, L. N. (2016). The influence of boarding school to young children: A case of two boarding schools in Hai District in Kilimanjaro, Tanzania. International Journal of Education and Research, 4(6), 73-84. Retrieved from https://www.ijern.com/journal/2016/June-2016/07.pdf

Lee, S. W. Y., Tsai, C., Wu, Y., Tsai, M., Liu, T., Hwang, F., ... Chang, C. (2011). Internet-based science learning: A review of journal publications. International Journal of Science Education, 33(14), 18931925. doi: https://doi.org/10.1080/09500693.2010.536998

Logan, J. W., Lundberg, O. H., Roth, L., \& Walsh, K. R. (2017). The effect of individual motivation and cognitive ability on student performance outcomes in a distance education environment. Journal of Learning in Higher Education, 13(1), 83. Retrieved from https://files.eric.ed.gov/fulltext/EJ1139727.pdf

Mahuro, G. M., \& Hungi, N. (2016). Parental participation improves student academic achievement : A case of Iganga and Mayuge districts in Uganda. Cogent Education, 4, 1-12. doi: https://doi.org/10.1080/23311 86X.2016.1264170

Martin, A. J., Papworth, B., Ginns, P., \& Liem, G. A. D. (2014). Boarding school, academic motivation and engagement, and psychological well-being. American Educational Research Journal, 51(5), 1007-1049. doi: https://doi.org/10.3102/0002831214532164

McComas, W. F., Reiss, M. J., Dempster, E., Lee, Y. C., Olander, C., Clément, P., ... Waarlo, A. J. (2018). Considering grand challenges in biology education: Rationales and proposals for future investigations to guide instruction and enhance student understanding in the life sciences. The American Biology Teacher, 80(7), 483-492. doi: https://doi.org/10.1525/abt.2018.80.7.483 
Memon, N. (2011). What islamic school teachers want: Towards developing an islamic teacher education programme. British Journal of Religious Education, 33(3), 285-298. doi: https://doi.org/10.1080/014162 00.2011 .595912

Miharja, F. J., Hindun, I., \& Fauzi, A. (2019). Critical thinking, metacognitive skills, and cognitive learning outcomes: A correlation study in genetic studies. Biosfer, 12(2), 135-143. doi: https://doi.org/10.21009/ biosferjpb.v12n2.135-143

Muwonge, C. M., Schiefele, U., \& Ssenyonga, J. (2017). Self-regulated learning among teacher education students: Motivational beliefs influence on the use of metacognition. Journal of Psychology in Africa, 27(6), 515-521. doi: https://doi.org/10.1080/14330237.2017.1399973

Naimnule, L., \& Corebima, A. D. (2018). The correlation between metacognitive skills and critical thinking skills toward students ' process skills in biology learning. Journal of Pedagogical Research, 2(2), 122134. Retrieved from http://ijopr.com/index.php/ijopr/article/view/50/24

Ogechukwu, D. O. F., \& Chika, N. P. (2018). Extent of academic achievement of day and boarding secondary schools students in Anambra State, Nigeria. International Journal of Scientific Research and Management, 6(1), 20-26. doi: https://doi.org/10.18535/ijsrm/v6i1.el03

Okoza, J., Aluede, O., \& Owens-Sogolo, O. (2013). Assessing students' metacognitive awareness of learning strategies among secondary school students in Edo State, Nigeria. Research in Education, (90), 83-97. doi: https://doi.org/10.7227/RIE.90.1.6

$\mathrm{Oz}, \mathrm{H}$. (2016). The importance of personality traits in students' perceptions of metacognitive awareness. In Procedia-Social and Behavioral Sciences (Vol. 232, pp. 655-667). doi: https://doi.org/10.1016/j.sbspro. 2016.10.090

Panchu, P., Bahuleyan, B., Seethalakshmi, K., \& Thomas, T. (2016). Metacognitive knowledge: A tool for academic success. International Journal of Medical Research Professionals, 2(5), 3-6. doi: https://doi. org/10.21276/ijmrp.2016.2.5.026

Pang, C., Lau, J., Seah, C. P., Cheong, L., \& Low, A. (2018). Socially challenged collaborative learning of secondary school students in Singapore. Education Sciences, 8(24), 1-10. doi: https://doi.org/10.3390/ educsci8010024

Reeve, E. M. (2016). 21st century skills needed by students in technical and vocational education and training. Asian International Journal of Social Sciences, 16(4), 62-74. doi: https://doi.org/10.29139/aijss. 20160404

Schraw, G., \& Dennison, R. S. (1994). Assessing metacognitive awareness. Contemporary Education Psychology, 19(4), 460-475. doi: https://doi.org/10.1006/ceps.1994.1033

Scott, C. L. (2015). The futures of learning 2: What kind of learning for the 21st century? Retrieved from https://unesdoc.unesco.org/ark:/48223/pf0000242996

Siswati, B. H., \& Corebima, A. D. (2017a). Study on the correlation between metacognitive skills and concept gaining of biology at several learning models. Asia-Pacific Forum on Science Learning and Teaching, 18, 1-14. Retrieved from https://eric.ed.gov/?id=EJ1160094.

Siswati, B. H., \& Corebima, A. D. (2017b). The effect of education level and gender on students' metacognitive skills in Malang, Indonesia. Advances in Social Sciences Research Journal, 4(4), 163168. doi: https://doi.org/10.14738/assri.44.2813

Song, D., \& Bonk, C. J. (2016). Motivational factors in self-directed informal learning from online learning resources. Cogent Education, 3(1), 1-11. doi: https://doi.org/10.1080/2331186X.2016.1205838

Tan, C. (2011). Where tradition and "modern" knowledge meet: Exploring two islamic schools in Singapore and Britain. Intercultural Education, 22(1), 55-68. doi: https://doi.org/10.1080/14675986.2011.549645

Thoha, I., \& Wulandari, D. (2016). The effect of parents attention and learning discipline on economics learning outcomes. Journal of Research \& Method in Education, 6(2), 100-104. doi: https://doi.org/10.9 790/7388-060201100104

Tzohar-Rozen, M., \& Kramarski, B. (2014). Metacognition, motivation, and emotions: contribution of selfregulated learning to solving mathematical problems. Global Education Review, 1(4), 76-95. Retrieved from https://files.eric.ed.gov/fulltext/EJ1055263.pdf

Veenman, M. V. J., Hesselink, R. D., Sleeuwaegen, S., Liem, S. I. E., \& Van Haaren, M. G. P. (2014). Assessing developmental differences in metacognitive skills with computer logfiles: Gender by age interactions. Psihologijske Teme, 23(1), 99-113. Retrieved from https://hrcak.srce.hr/index.php? 